\title{
Áttörés a kockázati mutatók validációjában - Megnyílt az út a várható többletveszteség effektív visszateszteléséhez?*
}

\author{
Bugár Gyöngyi
}

Ez az írás egyfajta „figyelemfelhívás” kiván lenni a pénzügyi kockázati mutatók viszszatesztelésében elért legújabb eredményekre. A téma a bankok által a kereskedési könyv portfóliókhoz szükséges minimális tökeigényének meghatározásához használt belső kockázati modellek teljesítményének szabályozói ellenőrzéséhez kapcsolódik. A visszatesztelési eljárás (backtesting) során a kockázatbecslő modellek helytállóságát ellenörizzük. A közelmúltban megjelent átütő szakirodalmi eredmények birtokában megállapítjuk, hogy a kockáztatott értékkel való együttes elicitálhatóságra (elicitability, kiválthatóság) építve a várható többletveszteséghez (expected shortfall) bevezethetö az úgynevezett közvetett utóteszt (ridge backtest ${ }^{1}$ ). Az azonban még nyitott kérdés, hogy mikor és hogyan fognak a szabályozó hatóságok erre reagálni.

Journal of Economic Literature (JEL) kódok: D81, G21, G28

Kulcsszavak: banki szabályozás, várható többletveszteség (ES), elicitálhatóság, viszszatesztelhetőség, közvetett utóteszt

\section{Bevezetés}

A 2016-ban közzétett új Bázel III szabályozás (BCBS 2016) módosított keretrendszert biztosít a piaci kockázatok tőkeköltségének meghatározásához a belső modellekben, és a hangsúlyt a kockáztatott értékről (Value at Risk, VaR) a várható többletveszteségre (Expected Shortfall, ES) helyezi (Bugár - Ratting 2016). Ez olyan kockázati mutató, amellyel jobban megragadható a nagy veszteségek bekövetkezésének koc-

\footnotetext{
* A jelen kiadványban megjelenő írások a szerzők nézeteit tartalmazzák, ami nem feltétlenül egyezik a Magyar Nemzeti Bank hivatalos álláspontjával.

Bugár Gyöngyi egyetemi docens a Pécsi Tudományegyetem Közgazdaságtudományi Karán. Email: bugar.gyongyi@ktk.pte.hu

A kutatást az Innovációs és Technológiai Minisztérium Felsőoktatási Intézményi Kiválósági Programja finanszírozta, a Pécsi Tudományegyetem 4. tématerületi programja - A hazai vállalatok szerepének növelése a nemzet újraiparosításában - keretében. A szerző köszönetet mond a két anonim lektornak az értékes észrevételeikért és javaslataikért.
}

Az angol nyelvű kézirat 2019. június 17-én érkezett szerkesztőségünkbe.

DOI: http://doi.org/10.25201/HSZ.18.4.130145

${ }^{1}$ Backtest: A korábbi tapasztalatokra épülő minősítési módszer. A magyar szakirodalomba visszatesztelés, illetve utóteszt elnevezéssel került át. 
kázata (tail risk), és kedvezőbb tulajdonságokkal rendelkezik, például koherenciával (Artzner et al. 1999).

Ahogyan azonban azt Gneiting (2011) korszakalkotó múvében bebizonyította, az ES-nek a VaR-ral szemben van egy komoly hátránya, mégpedig az, hogy nem elicitálható. Ez a megállapítás heves vitákat váltott ki azzal kapcsolatban, hogy egyáltalán lehetséges-e az ES visszatesztelése. Néhányan arra jutottak, hogy ez a kockázati mutató egyáltalán nem visszatesztelhető (például Carver 2013). Mások, mint például Tasche (2014) és Acerbi - Székely (2014) határozottan meg voltak győződve arról, hogy ez nem valós probléma. Utóbbiak hangsúlyozták, hogy az elicitálhatóságot nem is használták ki a VaR utótesztjeiben. Az elicitálhatóság hiánya az ES esetében komoly kihívásnak bizonyult. Ezért sokan, fóleg a pénzügyi matematikusok és a statisztikusok azt vizsgálták, hogy az ES alkalmas-e a VaR helyettesítésére a banki szabályozásban. Erre a célra elméletileg prominens jelölt lehet az $\alpha$-expektilis ${ }^{2}$, ami elicitálható és koherens is egyben $(\alpha \geq 0,5)^{3}$. A gyakorlati alkalmazása azonban kizárt, mivel nem bír semmilyen közgazdasági jelentéssel. Annak ellenére, hogy az ES megvetette a lábát a Bázel III-ban, és ezt használják javasolt új mérőszámként a kereskedési könyvben vállalt pozíciók tőkeköltségének megállapításához, a Bázeli Bizottság visszatesztelési célokra továbbra is a VaR-t támogatja.

A visszatesztelési módszertan legutóbbi fejleményeinek fényében égetően szükséges a jelenlegi rendszer felülvizsgálata. Ez a munka azokra az elképzelésekre és eredményekre kíván rávilágítani, amelyek alapot szolgáltattak a fenti, messzire mutató következtetés levonásához.

\section{Kockáztatott érték és várható többletveszteség}

McNeil et al. (2015) szerint a kvantitatív kockázatkezelés legmodernebb módszere az, hogy egy portfólió kockázatát olyan statisztikai mennyiségként azonosítják, amely megmutatja a portfóliónak egy előre meghatározott időhorizontra vonatkozó hozam/veszteség eloszlását. Ennek egyik példája a Markowitz (1952) által javasolt variancia, a VaR és az ES, mely utóbbiak a banki szabályozásban is alkalmazott mérőszámok. ${ }^{4}$

A VaR kvantilis alapú kockázati mérték (Dowd-Blake 2006), tehát az (X) hozameloszlás negatív $\alpha$-kvantilise adott $\alpha$ szignifikanciaszinten

$$
\operatorname{VaR}_{\alpha}(X)=-q_{\alpha}(X)
$$

\footnotetext{
${ }^{2}$ Az expectile fogalma, amely a várható érték általánosításának is tekinthető, Newey és Powell (1987) tanulmányában jelent meg először az angol szakirodalomban. Lévén, hogy magyar megfelelője után kutatva nem találtam létező elnevezést, egy korábbi tanulmányomban (Bugár 2019) expektilis néven vezettem be a magyar szakirodalomba.

${ }^{3}$ Lásd pl. Ziegel (2016) művét, ami ezt bizonyítja.

${ }^{4} \mathrm{~A}$ VaR egy adott időtávra vonatkozóan, meghatározott megbízhatósággal becsült legnagyobb veszteség. $\mathrm{Az}$ ES a VaR-t meghaladó átlagos veszteség.
} 
Az (1) egyenletből következően

$$
\operatorname{VaR}_{\alpha}(X)=-F^{\leftarrow}(\alpha), \quad 0<\alpha<1
$$

$F^{\leftarrow}(\alpha)$ az $X$ valószínúségi változó $F(x)$ eloszlásfüggvényének általánosított inverze (Embrechts et al. 1999), azaz

$$
F^{\leftarrow}(\alpha)=\inf \{x \in \mathbb{R} \mid F(x) \geq \alpha\}
$$

ahol inf\{.\} a zárójelben szereplő számhalmaz infimumát, azaz legnagyobb alsó korlátját jelenti. ${ }^{5}$

A VaR-módszertant a bankszektor 1993 óta használja úgynevezett standard szabályozási modell formájában, arra a célra, hogy felmérje a piaci kockázattal kapcsolatos veszteségek fedezéséhez szükséges szabályozói tőkét. A pénzügyi szektor dinamikus fejlődése gyors termékinnovációkkal párosult, és egyre több problémát és kihívást vet fel a szabályozók számára. Többek között a subprime (másodrendű hitelpiacról kiinduló) válság és globális pénzügyi válsággá történő eszkalációja is rávilágított a VaR mint kockázati mérőszám hátrányaira. A pénzügyi turbulencia ezen időszakában a bankok veszteségei messze meghaladták a VaR segítségével „kalibrált” szabályozói tőkekövetelményeket.

A VaR mint kockázati mérőszám megbízhatatlanságára a kutatók és a kockázati szakértők a 2000-es évek eleje óta határozottan rá is mutattak. Számos olyan tanulmány megjelent, amely a VaR „gyengeségeit” taglalta. Ezenfelül 2002-ben a Journal of Banking and Finance külön kötetet szentelt a VaR kockázatmérési teóriákban és a kockázatkezelésben történő alkalmazásában felmerülő problémáknak. Mi több, Szegö (2002) azt a provokatív címet adta szerkesztői előszavának, hogy „Soha többé VaR (ez nem sajtóhiba)". A kockázatmérési teória képviselői által küldött figyelmeztető jelzéseket azonban a bankok szabályozásáért felelős döntéshozók a 2007-es subprime-válság kirobbanásáig nem vették komolyan.

A feltételes kockáztatott érték (Conditional Value-at-Risk - CVaR) és Tail-VaR néven is emlegetett kockázati mutatót végül várható többletveszteség (ES) néven fogadta el a Bázeli szabályozás. ${ }^{6}$ Adott $\alpha$ szignifikanciaszinten (előre meghatározott időhorizonton) az ES feltételes várható érték, azaz a VaR-t meghaladó veszteség (negatív hozam) várható értéke. Acerbi - Tasche (2002) szerint ezt az alábbi módon lehet megfogalmazni:

$$
E S_{\alpha}(X)=\operatorname{VaR}_{\alpha}(X)+\frac{1}{\alpha} E\left(X+\operatorname{VaR}_{\alpha}\right)_{-}{ }^{7}
$$

\footnotetext{
${ }^{5} \mathrm{Ha}$ az $\alpha$-kvantilisnek egy értéke van, akkor a $V a R_{\alpha}$ meghatározható úgy is, mint az $\alpha$ eloszlásfüggvény negatív inverze, nevezetesen $\operatorname{VaR}_{\alpha}(X)=-F^{-1}(\alpha)$.

${ }^{6} \mathrm{~A}$ részleteket lásd $B C B S$ (2016) és Bugár - Ratting (2016).

${ }^{7} \mathrm{~A}$ fentiekben $(a)_{-}=-\min (a, 0)$, amit az $a$ negatív részének nevezünk.
} 
Folytonos hozameloszlásra a (4) egyenlet az alábbi alakot ölti:

$$
E S_{\alpha}(X)=\frac{1}{\alpha} \int_{0}^{\alpha} \operatorname{VaR}_{p}(X) d p
$$

A VaR-hoz képest az ES rendkívül kedvező teoretikus és empirikus tulajdonságokkal rendelkezik. A VaR-on túli veszteségeket is számba veszi, ami vastag szélű eloszlás esetén különösen fontos. Emellett koherens kockázati mérték is, ami megfelel az Artzner et al. (1999) által javasolt koherencia-axiómáknak. Ezzel ellentétben a VaR nem koherens, mivel nélkülözi a szubadditivitást. Így aztán előfordulhat, hogy egy portfólió VaR-ral mért kockázata magasabb, mint a komponensek kockázatának összege. Az ES rendelkezik két kedvező technikai tulajdonsággal is: A konfidenciaszint vonatkozásában folytonos, a kontrollváltozók függvényében pedig konvex, ez utóbbi a portfólió-optimalizálásban játszik fontos szerepet. A várható hozam-ES hatékony portfóliók meghatározásához, ahogyan azt Rockafellar - Uryasev (2000) megmutatta, ${ }^{8}$ mindössze egy lineáris programozási problémát kell megoldani. Ez nagyon vonzóvá teszi az ES-t az eszközallokációban.

Az elicitálhatóság hiánya mellett az ES egyéb hiányosságokkal is rendelkezik. Ezek közül, ahogyan azt Csóka et al. (2007) bemutatta, érdemes megemlíteni, hogy amikor egy portfólió kockázatát az általános egyensúlyelmélet szempontjából értékeljük, akkor a spektrális kockázati mutatók (az ES általánosításai) nem veszik figyelembe a vizsgált portfóliónak a piaci portfólióval fennálló viszonyát. Ennek következtében az ES mint kockázati mutató alkalmazása a portfólió kockázatának alul- vagy felülbecsléséhez vezethet.

\section{Modellvalidáció}

A modellvalidáció kifejezés általánosságban arra a folyamatra utal, amellyel ellenőrizzük, hogy egy modell megbízható előrejelzéseket ad-e. A kockázatkezelésben és a pénzügyi szabályozásban a modellvalidációhoz használt módszert visszatesztelésnek (backtesting) nevezzük. Ahogyan azt Acerbi - Székely (2017) kifejezte, a viszszatesztelés „a [modell] outputjának az ellenőrzése”. Másképpen kifejezve olyan technika, amellyel értékelni lehet az előrejelzési módszer pontosságát oly módon, hogy összehasonlítjuk az előzetes statisztikai előrejelzéseket az adott valószínúségi változók tényleges alakulásával. A nehézség abban rejlik, hogy a statisztikáknak sem a valós értékét, sem pedig az eloszlását nem lehet feltárni. Utólagosan kizárólag azt a realizált értéket lehet megtalálni, amely egy véletlenszerüen kiválasztott adatnak tekinthető (egy minta egy eleme).

\footnotetext{
${ }^{8}$ Az ES-re a CVaR elnevezést használták.
} 
Így a kockázatmérésben figyelembe vett statisztika egy kockázati mutató pontbecslése, ami például a VaR vagy az ES esetében a (2), illetve (4) egyenlettel kapható meg. A hozam $(X)$ a megfelelő valószínúségi változó, az $F(x)$ pedig ennek eloszlásfüggvénye. Ha egy konkrét modellre támaszkodunk, nevezetesen egy olyan módszerre vagy algoritmusra, amellyel megbecsüljük az alkalmazott kockázati mutatót, akkor az a feladatunk, hogy értékeljük az előre jelzett teljesítményt a realizált hozamok idősora alapján $\left(x_{t}\right)$, és összehasonlítsuk ezeket a kockázati mutatók előrejelzéseivel $\left(y_{t}\right)$. Ez utóbbi a releváns kockázati mutató becsült értéke, melyet a $t-1$ időpontban megadtunk a $t$ időponthoz tartozóan. Ez a folyamat egy másik kihíváshoz vezet, különösen az ES-utótesztek esetében. Mivel az ES valódi értékét nem lehet megfigyelni, a kockázat mértékére vonatkozó előrejelzéseket a hozameredmények alapján kell ellenőrizni. Ahogy Acerbi - Székely (2019) megfogalmazta, ebben az esetben lényegében „almát naranccsal” hasonlítunk össze.

A modellvalidációnak két fontos típusát ismerjük. Az abszolút validáció esetében egy adott, előre meghatározott modell előrejelző képességét értékeljük. Ez a hagyományos megközelítés, melynek célja egyetlen belső modellnek a pénzügyi szabályozók által történő visszatesztelése. Erre a célra a hipotézisvizsgálat módszertanát alkalmazzák.

A modellvalidáció másik típusa a relatív validáció vagy modellkiválasztás, ahogyan azt Acerbi - Székely (2014) nevezték. Ezt akkor használják, amikor a cél különböző modellek rangsorolása az előrejelzési képességeik alapján. Ilyen helyzetben rendkívül előnyösnek bizonyulhat az elicitálhatóságnak nevezett tulajdonság.

\section{Elicitálhatóság és visszatesztelhetőség}

\subsection{Az elicitálhatóság és a visszatesztelhetőség jelentősége}

Az elicitálható statisztikák közös jellemzője, hogy minimálisra csökkentik egy hibafüggvény várható értékét. A hibafüggvénynek az a szerepe, hogy számszerűsítse az előre jelzett és a realizált érték közötti különbséget. A hibafüggvénynek szigorúan konzisztensnek kell lennie, ami azt jelenti, hogy várható értéke (átlaga) véges és a várható értékének van egyértelmú minimuma. Az elicitálhatóság formális meghatározása az alábbiak szerint adható meg (lásd McNeil et al. 2015):

Legyen $R: X \rightarrow R(X)$ egy olyan kockázati mutató, amelyet az $X$ hozam $F(x)$ eloszlásfüggvényén definiálunk. Az $R$ kockázati mutató úgy is értelmezhető, mint egy $F$-en definiált $T$ statisztika (becslőfüggvény), így $T: F \rightarrow T(F)$. Ez a kapcsolat úgy is kifejezhetö, hogy $R(X)=T(F)$. 
Egy kockázati mutató $T$ becslőfüggvénye akkor elicitálható, ha létezik egy $S: \mathbb{R} \times \mathbb{R} \rightarrow[0, \infty)$ erősen konzisztens hibafüggvény, amelyre minden véges várható értékkel rendelkező $X$ hozamra teljesül a következő:

$$
T(F)=\operatorname{argmin}_{y \in \mathbb{R}} E(S(y, x))
$$

ahol a $E($.$) a várható értéket jelenti. Felhívjuk a figyelmet, hogy a hibafüggvény$ értékei nem lehetnek negatívak. ${ }^{9}$

Ahogyan az előrejelzés-elméletben ismeretes, a várható érték elicitálható, a megfelelő hibafüggvény pedig $S(y, x)=(y-x)^{2}$. Bizonyítható, hogy a VaR elicitálható a szigorúan növekvő eloszlásfüggvények esetében. ${ }^{10} \mathrm{Az}$ ES azonban, ahogyan azt Gneiting (2011) kimutatta, nem elicitálható. Érdemes megemlíteni, hogy Bellini - Bignozzi (2015) ugyanezt bebizonyította a pénzügyi kockázatmérés elmélete szempontjából úgy, hogy jellemzett minden elicitálható kockázati mutatót. A variancia, amelyet Markowitz (1952) vezetett be kockázati mutatóként, szintén nem elicitálható (Lambert et al. 2008). A fenti példákat az 1. táblázat foglalja össze. Az elicitálható statisztikák esetén a releváns (kanonikus) hibafüggvényt is feltüntettük a táblázatban.

1. táblázat

Példák elicitálható és nem elicitálható statisztikákra

\begin{tabular}{l|c|c}
\hline Statisztika & Elicitálható? & Hibafüggvény \\
\hline Várható érték & Igen & $(y-x)^{2}$ \\
\hline Variancia & Nem & Nem létezik \\
\hline $\mathrm{VaR}_{\alpha}$ & Igen & $(1-\alpha)(y-x)_{\{x<y\}}+\alpha(y-x)_{\{x \geq y\}} *$ \\
\hline $\mathrm{ES}_{\alpha}$ & Nem & Nem létezik \\
\hline
\end{tabular}

Megjegyzés: * Ez abszolút értékkel is kifejezhető: $\left|1_{\{x \leq y\}}-\alpha\right||y-x|$.

Forrás: Acerbi - Székely (2017) alapján szerkesztve

Az elicitálhatóság hiánya az ES esetében olyan kihívásnak bizonyult, amely hibás következtetésekhez vezetett. Időközben bebizonyosodott, hogy ez a tulajdonság csak a relatív modellvalidációban lényeges (lásd pl. Davis 2014; Acerbi - Székely 2014; Fissler et al. 2015). Levonhatjuk tehát azt a következtetést, hogy ennek a tulajdonságnak semmi köze nincs az abszolút modellvalidációhoz.

Az elicitálhatóságnak a visszatesztelésben érvényesülő jelentősége abból a tényből ered, hogy lehetővé teszi a különféle kockázatbecslő modellek által adott $\left(y_{t}\right)$ előrejelzések értékelését, kizárólag a valószínúségi változók realizált értékére, konkrétan a realizált hozamok sorozatára $\left(x_{t}\right)$ alapozva. Ha a kockázati mutató elicitálható,

\footnotetext{
${ }^{9}$ A hibafüggvények tulajdonságaival és az elicitálható kockázati mutatókkal kapcsolatos további hivatkozásokat lásd Bugár (2019).

${ }^{10}$ Bizonyítás: lásd pl. McNeil et al. (2015).
} 
akkor a konkurens modelleket rangsorolni lehet a hibafüggvény egy bizonyos időszakra $(T)$ vonatkozó átlagos értékének kiszámításával:

$$
\bar{s}=\frac{1}{T} \sum_{t=1}^{T} S\left(y_{t}, x_{t}\right)
$$

A konkurens modelleket azon koncepció szerint lehet rangsorolni, hogy a kisebb átlagérték jobb előrejelző modellt jelent.

Miközben a visszatesztelés már régóta bevett gyakorlat a pénzügyi iparágban és a szabályozásban, legjobb tudomásunk szerint a formális definícióját csak a közelmúltban határozta meg Acerbi - Székely (2017).

\subsection{A visszatesztelhetőség meghatározása}

Egy kockázati mutató $T$ becslőfüggvénye akkor visszatesztelhető, ha létezik egy olyan $Z: \mathbb{R} \times \mathbb{R} \rightarrow \mathbb{R}$ visszatesztelési függvény, amelyre minden véges várható értékkel rendelkező $X$ hozamra teljesül a következő:

$$
E(Z(y, x))=0 \text { akkor, és csak akkor, ha } y=T(F)
$$

További követelmény, hogy a fenti $Z$ visszatesztelési függvénynek szigorúan monoton növekednie kell az y változó függvényében, tehát

$$
E\left(z\left(y_{1}, x\right)\right)<E\left(z\left(y_{2}, x\right)\right) \text { ha } y_{1}<y_{2}
$$

Említésre méltó, hogy a visszatesztelhetőséget azzal a céllal definiáljuk, hogy képesek legyünk megkülönböztetni a túl- és alulbecslést. A (8) egyenletben a pozitív értékek túlbecslést jelentenek, a negatív értékek pedig alulbecslést. A hibafüggvények nem rendelkeznek ilyen előjelfüggő tulajdonsággal. Szintén jól látható, hogy a rosszabb előrejelzések a nullától távolabb helyezkednek el.

Acerbi - Székely (2017) rámutatott, hogy a visszatesztelhetőség elicitálhatóságot is jelent az y változóban konvex hibafüggvények esetében. A megfelelő hibafüggvény a visszatesztelési függvény ismeretében az alábbiak szerint határozható meg:

$$
S(y, x)=\int^{y} z(t, x) d t
$$

feltéve, hogy létezik a fenti integrál.

Az igazi kihívás azonban abban rejlik, hogy egy kockázati mutató elicitálhatósága a visszatesztelhetőség szükséges feltételének bizonyult. Ez azt jelenti, hogy egy nem elicitálható statisztika nem is visszatesztelhető. Speciális esetként ebből az következik, hogy az ES nem visszatesztelhető. Ezen a ponton az ES ellenzői némileg fellélegezhetnek, de azért ezzel még nincs vége a történetnek. 
Másrészt viszont az y változóban szigorúan konvex és folytonos (tehát y szerint folytonosan differenciálható) hibafüggvény esetén fennálló elicitálhatóság visszatesztelhetőségre utal. Ebben az esetben az utóteszt függvényt az alábbiak szerint határozhatjuk meg:

$$
z(y, x)=\partial_{y} s(y, x)
$$

Mindezek alapján egyértelmúen levonhatjuk azt a következtetést, hogy a VaR visszatesztelhető (amennyiben a hozameloszlásra nézve bizonyos feltételek teljesülnek ${ }^{11}$ ). A 2. táblázat bemutat néhány példát visszatesztelhető és nem visszatesztelhető statisztikákra, és az előbbiekhez megadja a releváns visszatesztelési függvényt is.

2. táblázat

Példák elicitálható és nem elicitálható statisztikákra

\begin{tabular}{l|c|c}
\hline Statisztika & Visszatesztelhető & Visszatesztelési függvény \\
\hline Várható érték & Igen & $y-x$ \\
\hline Variancia & Nem & Nem létezik \\
\hline $\operatorname{VaR}_{\alpha}$ & Igen & $(1-\alpha)_{\{x<y\}}-\alpha_{\{x>y\}}+c_{\{x=y\}}{ }$ \\
\hline $\mathrm{ES}_{\alpha}$ & Nem & Nem létezik \\
\hline
\end{tabular}

Megjegyzés: * A fenti c állandónak a $[-\alpha, 1-\alpha]$ tartományban kell lennie. A részleteket lásd: Acerbi Székely (2017:10)

Forrás: Acerbi - Székely (2017) alapján szerkesztve

Hasonlóan ahhoz a módszertanhoz, amellyel az elicitálhatóságot ki lehet használni a modellszelekcióban (relatív modellvalidáció), a realizált visszatesztelési függvényt is alkalmazhatjuk a konkurens modellek rangsorolásához, ha kiszámítjuk az átlagos visszatesztelési értéket egy $T$ időszakra, a kockázatimutató-előrejelzések $\left(y_{t}\right)$ sorozata, valamint a realizált hozamok alapján $\left(x_{t}\right)$ :

$$
\bar{z}=\frac{1}{T} \sum_{t=1}^{T} z\left(y_{t}, x_{t}\right)
$$

A (7) egyenletben megadott teszttel ellentétben a fenti teszt előjelfüggő, tehát pozitív (negatív) értékkel meg tudja állapítani a túl- vagy alulbecslésre utaló tendenciát. Szintén fontos kiemelni, hogy a (7) egyenletben megadott teszthez hasonlóan ez sem alkalmazható abszolút modellvalidációra. Ebben az esetben hipotézis-ellenőrzést kell végezni visszatesztelési eljárásként, ahogyan azt már korábban említettük. Az abszolút modellvalidációhoz szükséges eljárást Acerbi - Székely (2017) javasolták és írták le.

\footnotetext{
${ }^{11}$ A részleteket lásd: Acerbi - Székely (2017).
} 


\subsection{A visszatesztelés élessége}

Az Acerbi - Székely (2017) által megadott definíció szerint egy visszatesztelhető $T(F)$ statisztika akkor biztosít éles utótesztet, ha a visszatesztelési függvény várható értéke kizárólag az előre jelzett $(y)$ értéktől és a statisztika valódi értékétől $[T(F)]$ függ:

$$
E[z(y, X)]=\phi(y, T(F))
$$

A fentiekben a $\phi$ függvény y szerint szigorúan monoton növekvő, $T(F)$ szerint pedig szigorúan monoton csökkenő.

Amint azt a 2. táblázat mutatja, a várható érték visszatesztelési függvénye: $z(y, x)=y-x$. Jelölje az $m$ az előrejelzett értéket, és legyen $\mu$ az átlag valós értéke. Ekkor $E[Z(y, X)]=m-E(X)=m-\mu$, ami azt bizonyítja, hogy a várható érték utótesztje éles. A VaR ezzel ellentétben nem biztosít éles utótesztet. ${ }^{12}$

Az éles utóteszt rendelkezésre állása kulcsfontosságú, mivel ennek alapján lehet az adott statisztika igazi (valós) értékét előre jelezni. Ezen túlmenően egy éles utóteszt az elörejelzésben mutatkozó eltérés közvetlen mértékének is tekinthető, mivel mutatja az előre jelzett és a valós érték közötti különbséget.

\section{A vita megoldása - közvetett utóteszt (ridge backtesting)}

\subsection{A közvetett utóteszt formális definíciója}

A közvetett utóteszt koncepcióját Acerbi - Székely (2017) vezette be. Ez a magasabb rendű vagy együttes elicitálhatóság fogalmára épít (Acerbi - Székely 2014; Fissler et al. 2015; Fissler - Ziegel 2016).

A formális definíciót (Acerbi - Székely 2017) az alábbiak szerint lehet megadni. Egy $T_{2}$ statisztika akkor alkalmas közvetett utótesztre a

$$
z\left(y_{2}, y_{1}, x\right)=h\left(y_{2}\right)-v S\left(y_{1}, x\right)
$$

visszatesztelési függvénnyel, ha kifejezhető (egy szigorúan monoton $g: \mathbb{R} \rightarrow \mathbb{R}$ függvény erejéig) úgy, mint az $S$ hibafüggvény várható értékének minimuma egy elicitálható $T_{1}$ segédstatisztika felhasználásával, azaz:

$$
\begin{aligned}
& T_{2}(F)=g\left(\min _{y \in \mathbb{R}} E(S(y, x))\right) \\
& T_{1}(F)=\operatorname{argmin}_{y \in \mathbb{R}} E(S(y, X))
\end{aligned}
$$

A (14)-ben $v \in\{ \pm 1\}$ a $g^{\prime}$ (a $g$ deriváltjának) előjele és a $h(x) \equiv v g^{-1}(y)$.

\footnotetext{
${ }^{12}$ A részleteket lásd: Acerbi - Székely (2019)
} 
Amint az a (14)-es egyenletben látható, közvetett utóteszt esetében egy elicitálható segéd változó elörejelzése történik a kívánt (önmagában nem visszatesztelhető) statisztika visszatesztelési eljárásában. Az utóbbi egybeesik az előző hibafüggvénye várható értékének minimumával.

\subsection{Közvetett utóteszt a varianciához}

Mint korábban említettük, a variancia nem felel meg egy visszatesztelhető statisztikával szemben támasztott követelményeknek, mert nem elicitálható. Mégis lehetőség van közvetett utóteszt elvégzésére, ha kihasználjuk azt, hogy a varianciát kifejezhetjük a várható érték (átlag) hibafüggvénye várható értékének minimumaként. Valóban, a (15) szerint

$$
\begin{gathered}
V=\min _{m \in \mathbb{R}} E\left[(X-m)^{2}\right] \\
\mu=\operatorname{argmin}_{m \in \mathbb{R}} E\left[(X-m)^{2}\right]
\end{gathered}
$$

Ebből az következik, hogy a variancia visszatesztelési függvénye felírható úgy, hogy

$$
Z(v, m, x)=v-(x-m)^{2}
$$

$V$ és $\mu$ a fentiekben a variancia és az átlag valódi értékeit, míg $v$ és $m$ az előre jelzett értékeket jelentik.

A variancia utótesztje a $B(m)=(m-\mu)^{2}$ kvadratikus torzításig éles, ami mutatja a variancia előrejelzésének az átlag (várható érték) előrejelzésének pontosságára való érzékenységét (lásd Acerbi - Székely 2019).

\subsection{Közvetett utóteszt az ES-hez}

A Rockafellar - Uryasev (2002) által adott formális meghatározás alapján

$$
\begin{gathered}
E S_{\alpha}=\min _{v \in \mathbb{R}} E\left[v+\frac{1}{\alpha}(X+v)_{-}\right] \\
V a R_{\alpha}=\operatorname{argmin}_{v \in \mathbb{R}} E\left[v+\frac{1}{\alpha}(X+v)_{-}\right]
\end{gathered}
$$

Acerbi - Székely (2019) megmutatta, hogy az ES esetében alkalmazható közvetett utóteszt az alábbi visszatesztelési függvénnyel:

$$
z(e, v, x)=e-v-\frac{1}{\alpha}(x+v)_{-}
$$

ahol $\alpha$ az adott szignifikanciaszint, $e$ és $v$ pedig az ES és a VaR előre jelzett értékeit jelentik. A fenti teszt modellszelekcióhoz és abszolút modellvalidációhoz egyaránt használható. 
A visszatesztelési függvény várható értékét az alábbi módon fejezhetjük ki:

$$
E[Z(e, v, x)]=e-E S_{\alpha}-B(v)
$$

A (20) egyenletből látható, hogy a fenti ES utóteszt a

$$
B(v)=E\left[v+\frac{1}{\alpha}(X+v)_{-}\right]-E S_{\alpha} \geq 0
$$

torzítás erejéig éles. A torzítás értéke pozitív minden $v$ esetében, és nulla, ha a VaR előrejelzése pontos, tehát $v=V a R_{\alpha}$. Acerbi - Székely (2019) bizonyította, hogy folytonos hozameloszlás esetén a torzítás úgy is meghatározható, mint a VaR előrejelzésében mutatkozó eltérés kvadratikus függvénye ${ }^{13}$

$$
B(v) \approx \frac{f\left(-V a R_{\alpha}\right)}{2 \alpha}\left(v-V a R_{\alpha}\right)^{2}
$$

ahol $f$ a hozameloszlás sürűségfüggvényét jelenti. Ha a VaR előre jelzett és valós értéke között kicsi az eltérés, a torzítás is csekély. Szintén figyelemreméltó, hogy a $B(v)$ prudenciális hatással is bír ${ }^{14}$ olyan értelemben, hogy a nem pontos VaR-elörejelzés (rossz VaR-becslés) növeli az eltérést az ES előre jelzett és valódi értéke között (lásd a (20) egyenletet).

A (22)-ben megadott torzítás relatív mértékének illusztrálása céljából négy eloszlást vettünk figyelembe: a standard normálist és a Student-féle t eloszlást, három különböző szabadságfokra. ${ }^{15} \mathrm{~A}$ 3. táblázatban bemutatott számítások alapján a VaR előrejelzésének pontossága függvényében $(v-V a R) / v)$ meghatároztuk az ES előrejelzésében mutatkozó torzítás relatív nagyságát $(B(v) /|E S|)$. A kapott eredményeket az 1. ábra mutatja. A VaR és az ES kiszámítása során szignifikanciaszintként $\alpha=2,5$ százalékot alkalmaztunk. Érdemes megemlíteni, hogy a VaR-előrejelzésben előforduló negatív hiba alulbecslést jelez, míg a pozitív hiba túlbecslésre utal. Az ábrán látható, hogy a grafikonok aszimmetrikusak, ami azt jelzi, hogy a torzítás relatív mértéke érzékenyebb a VaR túlbecslésére, mint az alulbecslésére. A VaR előrejelzés függvényében azonban tág határokon belül alacsonyan lehet tartani a torzítás relatív mértékét. Így például -30 százalékos és 20 százalékos VaR-előrejelzési hiba esetén a torzítás relatív mértéke minden esetben (kivéve a normál eloszlást ${ }^{16}$ ) 10 százalék alatt marad.

\footnotetext{
${ }^{13}$ Lásd Acerbi - Székely (2017, 2019).

${ }^{14}$ Ez a torzítás nem negatív voltának köszönhető.

${ }^{15}$ Felhívjuk a figyelmet, hogy az előbbit generálhatjuk az utóbbiból, a végtelenhez konvergáló szabadságfokra.

${ }^{16}$ Még ebben az esetben is csak kevéssel haladja meg VaR alulbecslés esetén a 10 százalékot, túlbecslés esetén pedig a 12 százalék körüli értéket.
} 


\section{3. táblázat}

VaR, ES és a kvadratikus eltérés szorzója a standard normál és különféle Studentféle t eloszlásokra

( $\alpha=2,5$ százalék)

\begin{tabular}{l|c|c|c} 
Eloszlás & VaR $_{\boldsymbol{\alpha}}$ & ES $_{\boldsymbol{\alpha}}{ }^{*}$ & Szorzó ${ }^{* *}$ \\
\hline Student $\mathrm{t}(d f=2)$ & $-4,30$ & $-8,40$ & 0,22 \\
\hline Student $\mathrm{t}(d f=5)$ & $-2,57$ & $-3,52$ & 0,61 \\
\hline Student t $(d f=20)$ & $-2,09$ & $-2,97$ & 1,00 \\
\hline Standard normál & $-1,96$ & $-2,34$ & 1,17 \\
\hline
\end{tabular}

Megjegyzés: * A t eloszlásokra az ES értékét a Zhang (2016) által adott formula alapján határoztuk meg. **A szorzó a (22) összefüggésben szereplő $f(-V a R) / 2 \alpha$.

\section{1. ábra \\ A torzítás relatív mértéke a VaR előrejelzés hibájának függvényeként négy különböző eloszlásra ( $\alpha=2,5$ százalék)}

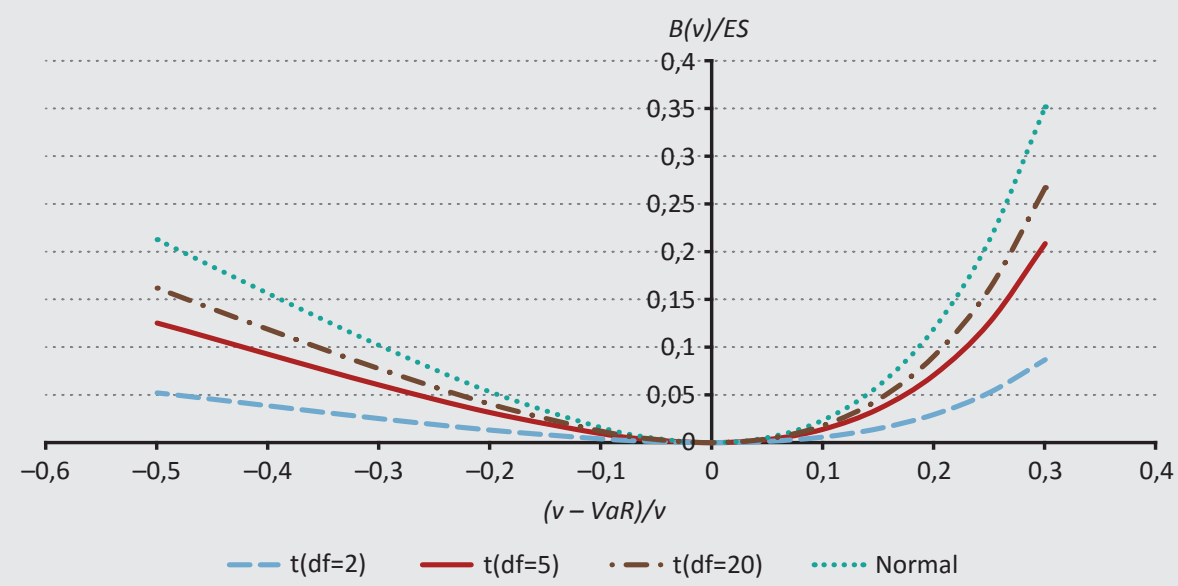

Forrás: Acerbi - Székely (2019) alapján számítva

Első látásra meglepőnek tűnhet, hogy a torzítás a vékonyabb szélű eloszlásoknál bizonyul erősebbnek. Ez a javasolt utóteszt „okos” sajátosságának is tekinthető, és úgy magyarázható, mint egyfajta büntetés a rosszul specifikált modell használatáért (lásd Acerbi-Székely 2019).

Acerbi - Székely (2019) legutóbbi munkájában a „realizált ES” kifejezés bevezetése jelenti az újdonságot. Ez a következő képlettel fejezhető ki:

$$
\widehat{E S}_{\alpha}=\frac{1}{T} \sum_{t=1}^{T} v_{t}+\frac{1}{\alpha}\left(x_{t}+v_{t}\right)_{-}
$$


Ennek azért tulajdoníthatunk értelmes jelentést, mert az ES-utóteszt éles. Az átlagos z-érték ugyanis $E[Z(e, v, X)]$ realizált értéke, (melyet a (20) egyenlet határoz meg, felírható az ES átlagos előre jelzett és realizált értéke közötti különbségként:

$$
\bar{z}_{E S_{\alpha}}\left(e_{t}, v_{t}, x_{t}\right)=\frac{1}{T} \sum_{t=1}^{T} e_{t}-\frac{1}{T} \sum_{t=1}^{T} v_{t}-\frac{1}{\alpha}\left(x_{t}+v_{t}\right)_{-}
$$

A fenti eredmény jelentősége abban áll, hogy lehetővé teszi az ES előre jelzett (ex-ante) és realizált (ex-post) értékének összehasonlítását, és ezzel végső soron - Acerbi - Székely (2019) megfogalmazása szerint - az „almát az almával” jellegű összehasonlításokat.

\section{6. Összefoglalás és következtetések}

Ez a munka arra tesz kísérletet, hogy felhívja a figyelmet arra a tényre, hogy létezik használható visszatesztelési módszertan az ES-hez. Ezt a kockázati mutatót 2016-ban fogadta el a Bázeli szabályozás a kereskedési könyvek pozíciói tőkeköltségének belső modellekben történő meghatározásához. Noha a tudósok és a pénzügyi szakemberek szempontjából előrelépésnek tekinthető, az ES átvétele ellentmondásos is abban az értelemben, hogy a VaR-t megtartották a modellek visszateszteléséhez.

Nagy kihívásnak bizonyult az a tény, hogy az ES nem elicitálható. Ezen túlmenően újabb kihívást jelent a visszatesztelhetőség formális definiálása és az elicitálhatósággal fennálló kapcsolatának feltárása. Egy közelmúltban megjelent, áttörést jelentő tanulmányban Acerbi - Székely (2017) rámutatott, hogy az ES, tehát az a kockázati mutató, amely már megvetette a lábát a banki szabályozásban, nem viszszatesztelhető. Ugyanebben a tanulmányban azonban a szerzők arra is rámutattak, hogy lehetőség van az ES-en egy úgynevezett közvetett utótesztet végezni, melyhez szükséges a VaR előrejelzése, ami pedig elicitálható. Ez azon az elképzelésen alapul, hogy az ES a VaR-ral együttesen elicitálható, ahogyan azt Fissler - Ziegel (2016) megmutatta. A közvetett utóteszt egyik szimpatikus tulajdonsága, hogy korlátozott mértékben érzékeny a VaR előrejelzésére, és ismert a torzítás iránya. Ezen felül, az éles visszatesztelés koncepciójára építve, legutóbbi munkájukban Acerbi és Székely (2019) bebizonyították, hogy lehetséges bevezetni a „realizált ES” fogalmát, ami a „tail risk” ex-post mértéke lehet.

Ezek a jelentős eredmények utat nyitnak az ES tényleges visszatesztelése előtt. A módszertan tehát használatra kész, és várja a pénzügyi szabályozók (re)akcióit. Ebben a vonatkozásban ígéretes előrelépést jelent, hogy az ES Acerbi és Székely által kidolgozott visszatesztelését jelenleg vizsgálja az Olasz Központi Bank kockázatkezelő csoportja a bank saját portfóliójának validálására. Eddig nagyon pozitívak a visszajelzések (Cesa 2019). A módszer kezdeti elismerését és az eredmények iránti 
növekvő érdeklődést egy közelmúltban készített podcast is jól mutatja, melyben interjút készítettek Acerbivel ${ }^{17}$ a Székellyel közösen kidolgozott és javasolt új módszertanról.

\section{Felhasznált irodalom}

Acerbi, C. - Székely, B. (2014): Backtesting Expected Shortfall. Risk Magazine, 27: 76-81.

Acerbi, C. - Székely, B. (2017): General Properties of Backtestable Statistics. Working paper. https://doi.org/10.2139/ssrn.2905109

Acerbi, C. - Székely, B. (2019): The minimally biased backtest for ES. Risk.net, 29 August. https://www.risk.net/cutting-edge/banking/6947266/the-minimally-biased-backtest-fores. Letöltve: 2019. szeptember 6 .

Acerbi, C. - Tasche, D. (2002): On the coherence of expected shortfall. Journal of Banking and Finance, 26(7): 1487-1503. https://doi.org/10.1016/S0378-4266(02)00283-2

Artzner, P. - Delbaen, F. - Eber, J.M. - Heath, D. (1999): Coherent Measures of Risk. Mathematical Finance, 9(3): 203-228. https://doi.org/10.1111/1467-9965.00068

BCBS (2016): Basel Committee in Banking Supervision: Minimum Capital Requirements for Market Risk. Bank for International Settlements. 1-88.

Bellini, F. - Bignozzi, V. (2015): Elicitable Risk Measures. Quantitative Finance, 15(5): 725-733. https://doi.org/10.1080/14697688.2014.946955

Bugár Gyöngyi (2019): Kockázati mértékek becslésének igazolása. Statisztikai Szemle, 97(8): 731-748. https://doi.org/10.20311/stat2019.8.hu0731

Bugár Gyöngyi - Ratting Anita (2016): A piaci kockázat számszerüsitésének változása a Bázel III szabályozásban. Hitelintézeti Szemle, 15(1): 33-50. https://hitelintezetiszemle.mnb.hu/ letoltes/2-bugar-ratting.pdf

Carver, L. (2013): Mooted VaR substitute cannot be back-tested, says top quant. Risk, 8 March.

Cesa, M. - Osborn, T. (2019): Podcast: Acerbi on backtesting ES and FRTB's patchwork rules. Risk.net (Cutting Edge: Views), 30 August. https://www.risk.net/riskmanagement/6950496/podcast-acerbi-on-backtesting-es-and-frtbs-patchwork-rules. Letöltve: 2019. szeptember 6.

\footnotetext{
${ }^{17} \mathrm{Az}$ interjút Cesa és Osborn készítette, és a következő címen érhető el: https://www.risk.net/riskmanagement/6950496/podcast-acerbi-on-backtesting-es-and-frtbs-patchwork-rules (lásd a következő referenciát: Cesa-Osborn 2019).
} 
Cesa, M. (2019): Backtesting expected shortfall: mission accomplished? Risk.net (Cutting Edge: Our take), 3 September. https://www.risk.net/our-take/6963251/backtestingexpected-shortfall-mission-accomplished. 2019. szeptember 6.

Csóka, P. - Herings, P.J.J. - Kóczy, L.Á. (2007): Coherent measures of risk from a general equilibrium perspective. Journal of Banking and Finance, 31(8): 2517-2534. https://doi. org/10.1016/j.jbankfin.2006.10.026

Davis, M. (2014): Consistency of internal risk measure estimates. SSRN Electronic Journal. https://doi.org/10.2139/ssrn.2342279

Dowd, K. - Blake, D. (2006): After VaR - The Theory, Estimation and Insurance Applications of Quantile-Based Risk Measures. Journal of Risk and Insurance, 73(2): 193-229. https:// doi.org/10.1111/j.1539-6975.2006.00171.x

Embrechts, P. - Resnick, S.I. - Samorodnitsky, G. (1999): Extreme Value Theory as a Risk Management Tool. North American Actuarial Journal, 3(2): 30-41. https://doi.org/10.10 80/10920277.1999.10595797

Fissler, T. - Ziegel, J.F. (2016): Higher Order Elicitability and Osband's principle. Annals of Statistics, 44(4): 1680-1707. https://doi.org/10.1214/16-AOS1439

Fissler, T. - Ziegel, J.F. - Gneiting, T. (2015): Expected Shortfall is jointly elicitable with Value at Risk - Implications for Backtesting. Working paper. https://arxiv.org/pdf/1507.00244. pdf. Letöltve: 2017. november 12.

Gneiting, T. (2011): Making and Evaluating Point Forecasts. Journal of the American Statistical Association. 106(494): 746-762. https://doi.org/10.1198/jasa.2011.r10138

Lambert, N. - Pennock, D.M. - Shoham, Y. (2008): Eliciting Properties of Probability Distributions. Proceedings of the 9th ACM Conference on Electronic Commerce, EC 08. https://doi.org/10.1145/1386790.1386813

Markowitz, H.M. (1952): Portfolio Selection. Journal of Finance, 7(1): 77-91. https://doi. $\operatorname{org} / 10.2307 / 2975974$

McNeil, A.J. - Frey, R. - Embrechts, P. (2015): Quantitative Risk Management-Concepts, Techniques and Tools. Princeton University Press. Princeton and Oxford.

Newey, W. K. - Powell, J.L. (1987): Asymmetric least squares estimation and testing. Econometrica, 55(4): 819-847. https://doi.org/10.2307/1911031

Rockafellar, R.T. - Uryasev, S. (2000): Optimization of Conditional Value-at-Risk. Journal of Risk, 2(3): 21-41. https://doi.org/10.21314/JOR.2000.038 
Rockafellar, R.T. - Uryasev, S. (2002): Conditional Value-at-Risk for General Loss Distributions. Journal of Banking and Finance, 26(7): 1443-1471. https://doi.org/10.1016/S03784266(02)00271-6

Szegö, G. (2002): No more VaR (this is not a typo). Journal of Banking and Finance, 26(7): 1247-1251. https://doi.org/10.1016/S0378-4266(02)00280-7

Tasche, D. (2014): Expected Shortfall is not elicitable. So what? Presentation held at the University of Hannover, 23 January. https://www.stochastik.uni-hannover.de/fileadmin/ institut/pdf/Talk_Tasche.pdf. Letöltve: 2017. November 12.

Zhang, S. (2016): Two Equivalent Parametric Expected Shortfall Formulas for T-Distributions. SSRN working paper. https://doi.org/10.2139/ssrn.2883935

Ziegel, J.F. (2016): Coherence and Elicitability. Mathematical Finance, 26(4): 901-918. https:// doi.org/10.1111/mafi.12080 